\title{
Organisational ambidexterity: a literature review using bibliometric methods
}

\section{Francisco García-Lillo*, Mercedes Úbeda-García and Bartolomé Marco-Lajara}

\author{
Department of Management, \\ University of Alicante, \\ Alicante, Spain \\ P.O. Box 99, E-03080, Alicante, Spain \\ Email: f.garcia@ua.es \\ Email: mercedes.ubeda@ua.es \\ Email: bartolome.marco@ua.es \\ *Corresponding author
}

\begin{abstract}
The present research work shows the results of an analysis about the existing literature on one of the 'topics' which is currently raising great interest among scholars and researchers in the fields of strategic management and organisation science, namely: organisational ambidexterity. More precisely, and seeking to identify and visualise the intellectual structure or knowledge base of the research developed in relation to this construct, a decision was made to analyse a total of 283 research papers which appeared after the publication in the journal California Management Review in the summer of 1996 of the seminal work by Tushman and O'Reilly III entitled 'Ambidextrous Organizations: Managing Evolutionary and Revolutionary Change', where these authors suggested that organisations need to explore and exploit simultaneously if they want to be ambidextrous. As for the methodology applied, it was based on the utilisation of bibliometric techniques - particularly citation analyses and author co-citation analyses (ACA) - and social networks analysis (SNA).
\end{abstract}

Keywords: organisational ambidexterity; organisation theory; exploration; exploitation; bibliometrics; citation analysis; author co-citation analysis; ACA; social networks analysis; SNA.

Reference to this paper should be made as follows: García-Lillo, F., Úbeda-García, M. and Marco-Lajara, B. (2017) 'Organisational ambidexterity: a literature review using bibliometric methods', Int. J. Bibliometrics in Business and Management, Vol. 1, No. 1, pp.3-25.

Biographical notes: Francisco García-Lillo is a Senior Lecturer of the Business Organization Department at the University of Alicante (Spain). He has a $\mathrm{PhD}$ in Business and Economic Sciences. His research interests are focused on the fields of strategic management, human resources management (HRM), entrepreneurship, and the organisation theory.

Mercedes Úbeda-García holds a PhD in Economic and Business Sciences at the University of Alicante. She is a lecturer and a researcher in the fields of strategic management and human resources management (HRM). 
Bartolomé Marco-Lajara is the Vice-Dean of the Faculty of Economic and Business Sciences at the University of Alicante (UA), where he is a lecturer too. He has a $\mathrm{PhD}$ in Economic and Business Sciences. His research has been developed in the fields of strategic management, alliances, and human resources management (HRM).

\section{Introduction}

Organisational ambidexterity, defined by O'Reilly and Tushman (2013) as "the ability of an organization to both explore and exploit - with the aim of competing in mature technologies and markets where efficiency, control, and incremental improvement are prized and to also compete in new technologies and markets where flexibility, autonomy, and experimentation are needed" (p.324), and regarded by these same authors as a dynamic capability (O'Reilly and Tushman, 2008, 2013), has strongly emerged as a central research stream in organisation science when trying to find an answer to the question: "how are organizations able to survive in the long term?"

To start with, having already become familiarised with the study of organisational ambidexterity, it would firstly seem advisable for us to state that the use of the aforesaid construct by scholars and researchers in the academic literature has traditionally been based on adopting a variety of analysis perspectives for the purpose of identifying those organisations which show a certain skill to explore new opportunities while contemporarily exploiting already existing capabilities (amongst others, Benner and Tushman, 2003; Birkinshaw and Gupta, 2013; Gibson and Birkinshaw, 2004; Gupta et al., 2006; He and Wong, 2004; O'Reilly and Tushman, 2008, 2013; Tushman and O'Reilly, 1996); in other words, which are capable of internally offsetting or balancing certain tensions while simultaneously managing to achieve aims that are apparently contradictory to each other: 'alignment' vs. 'adaptability,' 'flexibility' vs. 'efficiency,' 'stability' vs. 'change,' and 'exploitation' vs. 'exploration' (Adler et al., 1999; Gibson and Birkinshaw, 2004; Nosella et al., 2012).

With regard to the most important lines of research or fields of study around this perhaps new 'paradigm' in the context of the 'organisation theory', toward which research might evolve - a possibility mentioned by authors such as Raisch and Birkinshaw (2008, p.376) - researchers' efforts seem to have essentially focused on analysing its antecedents, moderating elements, and environmental influences - such as its high dynamism - as well as the effects on the 'performance' of organisational ambidexterity while contemporarily doing research on the different ways to achieve it; in short, on offsetting or trying to find a balance between 'alignment' (exploitation) and 'adaptability' (exploration).

In connection with the above, organisations regarded as ambidextrous can achieve the aforesaid balance between exploratory and exploitative processes in a variety of ways. One first way would be the utilisation of what is known as 'sequential ambidexterity.' For example, Siggelkow and Levinthal (2003) suggest that sequencing changes in the organisational structure to promote temporary decentralisation can be an effective way of exploring and exploiting. The 'balance' mentioned above could also be achieved by means of what is referred to as 'architectural' or 'structural' ambidexterity - also known as 'partitional' - in the literature. It consists in providing the organisation with a dual 
organisational structure where some units would be specialised in explorations and others in exploitation; and these units would in turn have different competences, incentive systems, processes and cultures —each one of them internally aligned [O'Reilly and Tushman, (2008), p.192]. Finally, contextual ambidexterity, defined as the conductual ability to show alignment - exploitation - as well as adaptability - exploration throughout a business unit [Gibson and Birkinshaw, (2004), p.209] could appear as a third way to reach such a balance. Unlike structural ambidexterity, this last type of ambidexterity - the 'contextual' one - is not obtained through the definition of dual structures but developing a series of systems or processes which allow or encourage individuals to judge by themselves what is the best way to divide their time as well as the resources which are available to them between exploratory and exploitative activities; ambidexterity thus becomes a capability which manifests itself in individuals rather than in the organisational structure itself (O'Reilly and Tushman, 2013).

In any case, if the previously listed 'ways' to achieve ambidexterity have something in common, that is the adoption of an internal perspective. Nevertheless, a new more recent analysis perspective seems to be emerging according to which ambidexterity is analysed through the adoption of a broader perspective that goes beyond organisational boundaries (Kauppila, 2010; Kristal et al., 2010; Lavie et al., 2010; Russo and Vurro, 2010; Stettner and Lavie, 2014; to quote but a few). In short, an approach or perspective where the firm (or corporation) stops being seen as the central unit of analysis, a role that now corresponds to the 'ecosystem' of which the firm is a part - by way of example, it has been proposed from the theoretical perspective of social networks that ambidexterity can be attained by means of strategic alliances between firms and inter-organisational networks able to combine exploratory and exploitative capabilities between different units and at different points in time (Lavie and Rosenkpof, 2006; Lavie et al., 2011; amongst others).

In particular, the research developed here not only allowed us to delimit the different lines or streams of research which shape the 'intellectual structure' of research on organisational ambidexterity - the goal of our work together with showing the highly multidisciplinary nature of the research performed in connection with such construct - but also offered sufficient evidence about the existence or presence of this other analytical 'front' or 'perspective' that authors such as Nosella et al. (2012) call 'cross-boundary' perspective.

Our paper is structured as follows. The next section - Section $2-$ deals with the collection of data that will subsequently be analysed from the source or database considered the most suitable one and with the methodology utilised. The outcome of the co-citation analyses and author co-citation analyses (ACAs) performed, together with a graphic representation or visualisation of the knowledge base or 'intellectual structure' mentioned in the preceding paragraph, that is, of the research carried out in relation to the construct examined, are shown in Section 3 - after which a final section serves to summarise the main conclusions and limitations of this research work.

\section{Data and methods}

The primary database from which were obtained the source documents used to carry out the present research study was the one developed by the Philadelphia Institute for 
Scientific Information (ISI): the Social Sciences Citation Index® (SSCI), available online through the Web of Science (WoS).

In particular, and with a view to identify and visualise the intellectual structure or knowledge base of the research on organisational ambidexterity, it was decided to analyse a total of 283 research papers ${ }^{1}$ about that construct which appeared after the publication in the journal California Management Review in the summer of 1996 of the seminal work by Tushman and O'Reilly III entitled 'Ambidextrous Organisations: Managing Evolutionary and Revolutionary Change,' where these authors suggested that organisations need to explore and exploit simultaneously if they want to be ambidextrous. The total number of cited references included in these papers amounted to 20,765, the resulting mean being 73.4 references per paper.

In relation to the above, it is worth highlighting that attention was exclusively paid to 'journal papers', that is, to research papers - instead of books, doctoral dissertations, or reviews and proceedings papers - since only these journal papers can be considered 'certified knowledge,' a term used to describe knowledge which has been subjected to the critical review of other researchers in order to gain their approval and which has resisted their objections (Callon et al., 1993). The use of citations coming from research papers additionally constitutes a standard practice adopted in this type of study for the purpose of increasing the validity level of the results obtained.

The documents retrieved were directly downloaded in plain text format (.txt) in order to be treated, after their conversion, through Bibexcel $\AA$, a public domain software program which can be downloaded on the internet for free. This software was specifically developed by Professor Olle Persson at the Institute of Information Sciences of the Swedish University of Umeå for the handling and treatment of bibliographic records.

Amongst many other functionalities, Bibexcel ${ }^{\circledR}$ offers the possibility to combine the information extracted from different fields of a bibliographic record, including the cited references field, to perform frequency counts and to analyse co-occurrence between various elements (authors, documents, journals, words, etc.), as well as the implementation of bibliographic coupling techniques.

In our case, the aforementioned software was used not only to carry out frequency counts for the citations contained in each one of the documents examined but also to generate the author co-citation matrix, after having pre-processed the data and established the cutoff point or citation threshold. The approach to the intellectual structure meant to be represented from the vision provided by social networks analysis (SNA) was based on the utilisation of the matrices previously generated with the Bibexcel ${ }^{\circledR}$ program for their treatment with Pajek ${ }^{\circledR}$ - their visualisation or reticular representation being carried out by means of VOSviewer ${ }^{\circledR}$. As for the different multivariate analyses performed, they were developed through the use of the statistical package SPSS ${ }^{\circledR}$ v.21.

At this stage, it is worth pointing out that the analysis of scientific maps cannot be directly applied to the data collected in gross format from the bibliographic databases; a previous pre-processing of those data is actually required. These data usually contain a large number of errors and inconsistencies mainly referred to their coding. On some occasions, for instance, there are elements which represent the same object or concept. Examples include an author's name or the title of a journal, which may appear written or coded in a wide variety of ways (e.g., Cyert, R or Cyert, Richard M; J. Manage. Stud. or Journal of Management Studies), or the different editions of one book. That is why the data had to undergo a careful normalisation process aimed at guaranteeing their accuracy. 
With regard to the choice of the documents which would ultimately form part of the analysis, in our specific case, due to the impossibility to work with all the data and since this type of analysis requires the need to establish a cutoff point for the selection of those papers which could be seen as the most influential ones or those having the strongest impact on the scientific community, a decision was made to consider all those documents which had been cited at least 17 times; or, expressed differently, those with citation levels exceeding $6 \%$ of the citing sample, thus obtaining a co-citation matrix $C$ with a $98 \times 98$ size, which would show the number of times - raw co-citation counts - the previously mentioned documents, taken by pairs, are jointly cited by the total of works included in the sample; in short, the absolute co-citation frequency for each pair of documents. ${ }^{2}$ This co-citation matrix has two main characteristics: firstly, it is a symmetrical matrix; and secondly, all the values in the main diagonal are zero, insofar as one document cannot be cited twice in the same paper.

Once the aforesaid co-citation matrix has been obtained, the following step in this sort of analysis - after deciding or establishing the treatment that is going to be given to the main diagonal values in the matrix so that they can reflect the maximum possible similarity of each 'paper' considered with itself $-{ }^{3}$ consists of obtaining a proximity matrix on which to apply (using the statistical packages SPSSC or STATAC, for instance) diverse multivariate analysis techniques oriented to reduce the dimensionality of the data examined, Pearson's r coefficient being - despite all the criticism that it has received (Ahlgren et al., 2003, 2004; Van Eck and Waltman, 2008) - one of the most often used measures similarities between pairs amongst a wide variety of normalisation strategies proposed in the area of bibliometrics (by way of example, see Van Eck and Waltman, 2009).

In the research work developed here, owing to our interest in implementing hierarchical cluster analysis as the main multivariate analysis technique and because that choice has proved to be particularly effective when developing such an analysis (e.g., Greene et al., 2008; Schäffer et al., 2011), a decision was made not to use Pearson's r coefficient, using a co-citation value or relative frequency known as CoCit-Score or index and proposed by Gmür (2003) instead as a similarity measure in order to achieve a 'similarity between pairs' matrix $S$ so that the similarity between each pair of documents $(\mathrm{Pi}, \mathrm{Pj})$ would be given by their absolute co-citation frequency normalised with respect to the minimum and the average number of citations received by each one of them separately considered:

$$
S_{i j}=\frac{C_{i j}^{2}}{\min \left(C_{i i}, C_{j j}\right) \times \operatorname{mean}\left(C_{i i}, C_{j j}\right)}
$$

More specifically, each $S i j$ entry would now be placed on the $[0,1]$ range, with a high value being indicative of a strong association between 'papers.'

It additionally deserves to be highlighted that the Cii entry located on the main diagonal would be made to tally in this case with the total number of citations received by paper $P i$.

In the previously calculated similarity matrix $S$ - now suitable indeed for the application of multivariate analysis - two barely cited authors or research works (both cited 40 times) with an absolute co-citation frequency of 20 , compared to another two often cited authors (100 times, for example) with the same co-citation value would 
receive a higher CoCit-Score ( 0.25 vs. 0.04$)$, from which it could be concluded that the said authors and/or documents are therefore more closely related to each other.

The next section shows the results of the citation analyses and ACAs - obtained, in this last case, from the application of a hierarchical cluster analysis of an agglomerative or upward nature on matrix $S$, for which purpose Ward's method was used as the agglomeration method - following the advice of authors such as Griffiths et al. (1984), McCain (1990) or Zitt and Bassecoulard (1996) to quote but a few. The section also provides a representation or visualisation corresponding to the intellectual structure of the research on the organisational ambidexterity analysed, made possible through the utilisation of the VOSviewer ${ }^{\circledR}$ tool.

The hierarchical methods mentioned above make it possible to build a classification tree - which is given the name of 'dendrogram' - where one can graphically analyse the combination procedure followed, showing which groups gradually combine with one another and on which specific level they do so, as well as the value of the measure for the association between groups when the latter are grouped together.

\section{Results and discussion}

The results obtained after completing the different stages that the developed analysis consists of are shown below.

Table 1 provides us with a list of the documents most often cited by the research papers about organisational ambidexterity published during the period under examination - which comes as the result of the citation analysis performed.

Table 1 List of the documents most often cited by the research papers about organisational ambidexterity

\begin{tabular}{llc}
\hline Ranking & Most-cited documents & Number of citations \\
\hline 1 & March (1991) & 187 \\
2 & Gibson and Birkinshaw (2004) & 170 \\
3 & Tushman and O'Reilly (1996) & 139 \\
4 & He and Wong (2004) & 137 \\
5 & Levinthal and March (1993) & 112 \\
6 & Benner and Tushman (2003) & 111 \\
7 & Raisch and Birkinshaw (2008) & 109 \\
8 & Gupta et al. (2006) & 99 \\
9 & Lubatkin et al. (2006) & 86 \\
10 & O'Reilly and Tushman (2004) & 75 \\
11 & Eisenhardt and Martin (2000) & 75 \\
12 & Smith and Tushman (2005) & 69 \\
13 & Raisch et al. (2009) & 67 \\
14 & Jansen et al. (2006) & 65 \\
15 & Teece et al. (1997) & 63 \\
16 & Duncan (1976) & 62 \\
17 & Adler et al. (1999) & 60 \\
\hline
\end{tabular}


Table 1 List of the documents most often cited by the research papers about organisational ambidexterity (continued)

\begin{tabular}{|c|c|c|}
\hline Ranking & Most-cited documents & Number of citations \\
\hline 18 & Katila and Ahuja (2002) & 58 \\
\hline 19 & Cohen and Levinthal (1990) & 55 \\
\hline 20 & O'Reilly and Tushman (2008) & 55 \\
\hline 21 & Leonard-Barton (1992) & 54 \\
\hline 22 & Cao et al. (2009) & 51 \\
\hline 23 & Birkinshaw and Gibson (2004) & 47 \\
\hline 24 & Brown and Eisenhardt (1997) & 45 \\
\hline 25 & Barney (1991) & 44 \\
\hline 26 & Lavie and Rosenkopf (2006) & 43 \\
\hline 27 & Christensen (1997) & 43 \\
\hline 28 & Podsakoff et al. (2003) & 42 \\
\hline 29 & Jansen et al. (2009) & 41 \\
\hline 30 & Andriopoulos and Lewis (2009) & 41 \\
\hline 31 & Burns and Stalker (1961) & 40 \\
\hline 32 & Yin (1984) & 40 \\
\hline 33 & Simsek (2009) & 36 \\
\hline 34 & Lawrence and Lorch (1967) & 35 \\
\hline 35 & Fornell and Larcker (1981) & 35 \\
\hline 36 & Aiken and West (1991) & 35 \\
\hline 37 & Eisenhardt (1989) & 34 \\
\hline 38 & Rothaermel and Deeds (2004) & 34 \\
\hline 39 & Kogut and Zander (1992) & 33 \\
\hline 40 & Floyd and Lane (2000) & 33 \\
\hline 41 & Teece (2007) & 32 \\
\hline 42 & Hair et al. (1998) & 31 \\
\hline 43 & Siggelkow and Levinthal (2003) & 31 \\
\hline 44 & Zahra and George (2002) & 31 \\
\hline 45 & Lewis (2000) & 30 \\
\hline 46 & Cyert and March (1963) & 30 \\
\hline 47 & Benner and Tushman (2002) & 29 \\
\hline 48 & Nelson and Winter (1982) & 29 \\
\hline 49 & Grant (1996) & 28 \\
\hline 50 & Henderson and Clark (1990) & 28 \\
\hline 51 & Rosenkopf and Nerkar (2001) & 28 \\
\hline 52 & Atuahene-Gima (2005) & 28 \\
\hline 53 & Ghoshal and Bartlett (1994) & 28 \\
\hline 54 & Gilbert (2005) & 25 \\
\hline 55 & Tushman and O'Reilly (1997) & 25 \\
\hline 56 & Holmqvist (2004) & 25 \\
\hline 57 & Zollo and Winter (2002) & 24 \\
\hline
\end{tabular}


Table 1 List of the documents most often cited by the research papers about organisational ambidexterity (continued)

\begin{tabular}{|c|c|c|}
\hline Ranking & Most-cited documents & Number of citations \\
\hline 58 & Rothaermel and Alexandre (2009) & 24 \\
\hline 59 & McGrath (2001) & 24 \\
\hline 60 & Anderson and Gerbing (1988) & 24 \\
\hline 61 & Thompson (1967) & 24 \\
\hline 62 & Burgelman (1991) & 23 \\
\hline 63 & Nahapiet and Ghoshal (1998) & 23 \\
\hline 64 & Baron and Kenny (1986) & 23 \\
\hline 65 & Porter (1980) & 23 \\
\hline 66 & Jansen et al. (2008) & 23 \\
\hline 67 & Danneels (2002) & 23 \\
\hline 68 & Mom et al. (2009) & 23 \\
\hline 69 & Armstrong and Evertong (1977) & 23 \\
\hline 70 & Lin et al. (1997) & 22 \\
\hline 71 & Powell et al. (1996) & 22 \\
\hline 72 & Podsakoff and Organ (1986) & 22 \\
\hline 73 & Ghemawat and Ricart (1993) & 22 \\
\hline 74 & Tushman and Anderson (1986) & 21 \\
\hline 75 & Auh and Menguc (2005) & 21 \\
\hline 76 & Simsek et al. (2009) & 21 \\
\hline 77 & Ahuja and Lampert (2001) & 20 \\
\hline 78 & Burgelman (2002) & 20 \\
\hline 79 & Damanpour (1991) & 20 \\
\hline 80 & Jaworski and Kohli (1993) & 20 \\
\hline 81 & Winter (2003) & 20 \\
\hline 82 & Jansen et al. (2005) & 20 \\
\hline 83 & Levitt and March (1988) & 20 \\
\hline 84 & Nonaka and Takeuchi (1995) & 20 \\
\hline 85 & Miles and Huberman (1994) & 20 \\
\hline 86 & Argyris and Schön (1978) & 20 \\
\hline 87 & Beckman (2006) & 19 \\
\hline 88 & Hannan and Freeman (1984) & 19 \\
\hline 89 & Mom et al. (2007) & 19 \\
\hline 90 & Sheremata (2000) & 18 \\
\hline 91 & Abernathy and Clark (1985) & 18 \\
\hline 92 & Chesbrough (2003) & 18 \\
\hline 93 & March and Simon (1958) & 18 \\
\hline 94 & Kyriakopoulos and Moorman (2004) & 18 \\
\hline 95 & Im and Rai (2008) & 17 \\
\hline 96 & Bagozzi and Youjae (1988) & 17 \\
\hline 97 & Crossan et al. (1999) & 17 \\
\hline 98 & Tripsas and Gavetti (2000) & 17 \\
\hline
\end{tabular}


The descriptive study of the aforesaid documents shows or provides the following research outcomes:

The papers written by March (1991) and Gibson and Birkinshaw (2004) lead the ranking of most highly cited works with a total of 187 and 170 citations received, respectively.

The works of Tushman and O'Reilly (1996), He and Wong (2004), Levinthal and March (1993), Benner and Tushman (2003), Raisch and Birkinshaw (2008), Gupta et al. (2006), Lubatkin et al. (2006), Eisenhardt and Martin (2000) and O'Reilly and Tushman (2004), these last two with the same number of citations received, 75, complete the top-ten.

As for the total of documents, the list comprises 81 research papers, 16 books and one chapter in a book. Table 2 shows the periodicals or journals in which the aforementioned papers were published.

Table 2 List of journals where the research papers listed on Table 1 have been published

\begin{tabular}{lccc}
\hline Title of journal & Frequency & Percentage & Total percentage \\
\hline Organization Science & 15 & $18.52 \%$ & $18.52 \%$ \\
Strategic Management Journal & 14 & $17.28 \%$ & $35.80 \%$ \\
Academy of Management Journal & 9 & $11.11 \%$ & $46.91 \%$ \\
Academy of Management Review & 8 & $9.88 \%$ & $56.79 \%$ \\
Administrative Science Quarterly & 7 & $8.64 \%$ & $65.43 \%$ \\
Journal of Management & 4 & $4.94 \%$ & $70.37 \%$ \\
Journal of Management Studies & 4 & $4.94 \%$ & $75.31 \%$ \\
Management Science & 3 & $3.70 \%$ & $79.01 \%$ \\
Others & 14 & $17.29 \%$ & $100 \%$ \\
TOTAL & 81 & $100 \%$ & \\
\hline
\end{tabular}

On the whole, what becomes visible is that a considerable proportion of these papers were published in the journal Organization Science $(18.52 \%)$. With regard to the remaining works, another four general management journals, all of them with a high impact factor - Strategic Management Journal (17.28\%), The Academy of Management Journal (11.11\%), The Academy of Management Review (9.88\%), and Administrative Science Quarterly (8.64\%) - accumulate nearly $50 \%$ of all the works published, a percentage which rises to nearly $60 \%$ if the papers published in Journal of Management and Journal of Management Studies are included as well.

Concerning the results obtained with the hierarchical cluster analysis, the application of that multivariate analysis technique on matrix $\mathrm{S}$, resulting from the ACA developed allowed us to identify the existence of up to 8 different groups or clusters.

The first of these clusters, or Cluster 1, includes the works of Yin (1984), Eisenhardt (1989) and Miles and Huberman (1994), all of them referring to the so-called or best known as 'case study research method' and to qualitative data analysis or research methodology, insofar as this is the methodology utilised in some of the most significant research works developed in the field of organisational ambidexterity.

The second cluster identified, or Cluster 2, gathers the papers by Christensen (1997), Tripsas and Gavetti (2000), Henderson and Clark (1990) and Tushman and Anderson (1986). More precisely, one book and three research papers focused on failure and on the 
main difficulties which are usually faced by already established firms when they have to adapt to changes operated in their business environment. ${ }^{4}$

As for Cluster 3, this cluster or group stands out amongst all the conglomerates for bringing together the highest number of research works. One can actually distinguish up to three different subgroups at a shorter distance, though.

The first of the aforesaid subgroups would be formed by the following eight documents, all of them research journals: Lewis (2000), Sheremata (2000), Birkinshaw and Gibson (2004), Beckman (2006), Jansen et al. (2008), Mom et al. (2007), Ghoshal and Bartlett (1994) and Baron and Kenny (1986). Considering the 'individual' level as their unit of analysis, some of these papers offer a discussion about a firm's ability to be ambidextrous, for example in terms of the exploration and exploitation activities developed by its executives and the extent to which these activities are influenced by intra-organisational knowledge flows, that is, according to their ambidextrous behaviour (Mom et al., 2007), their collective and creative actions (Sheremata, 2000), or the characteristics and attributes of the management team and the way in which it is shaped (Jansen et al., 2008; Beckman, 2006). The role generally played by contextual factors as a determining or contingent element of managerial action (Ghoshal and Barlett, 1994) or the moderating role of transformational leadership - the leadership which favours ambidexterity to a greater extent is characterised by its transformational style for authors such as Jansen et al. (2008) - are also analysed. It is finally worth highlighting that the paper written by Baron and Kenny (1986), in which its authors insist on the importance of not using the terms moderator and mediator interchangeably, insofar as they are different both conceptually and strategically, would also belong to this first subgroup.

The second subgroup would comprise the research papers listed below: Nahapiet and Ghoshal (1998), Crossan et al. (1999), Nonaka and Takeuchi (1995), Barney (1991), Grant (1996) and Argyris and Schön (1978); six documents in total - two books and four research papers - associated with organisational learning and the knowledge-based firm theory.

The third subgroup identified, with a total of 16 documents, would turn out to be the most heterogeneous of the three. The ouvres by Cyert and March (1963), March and Simon (1958), Porter (1980) and Nelson and Winter (1982) or Hannan and Freeman (1984) about the evolutionary approach or theory of economic change or the perspective of organisations' ecology would form part of this third subgroup. The works of Powell et al. (1996), Ahuja and Lampert (2001), Chesbrough (2003), Brown and Eisenhardt (1997), Jansen et al. (2005), Tushman and O'Reilly (1997), Burgelman (1991), Danneels (2002), Abernathy and Clark (1985), Damanpour (1991) and Benner and Tushman (2002) would complete this third subgroup.

In relation to Cluster 4, this conglomerate includes a total of 9 research works, all of them papers, where it is possible to distinguish two main subgroups closely linked to one another at a smaller distance.

The first of the subgroups mentioned above would comprise the works of Eisenhardt and Martin (2000), Teece et al. (1997), Zollo and Winter (2002), Winter (2003) and Teece (2007), all of them related to the theory of dynamic capabilities - it should be remembered that ambidexterity is precisely seen as a dynamic capability by authors such as O'Reilly and Tushman $(2008,2013)$ - a perspective which arose during the last decade with the aim of improving the explanatory capacity of the Resource-Based View of the Firm with respect to the achievement of a sustainable competitive advantage by firms operating in highly changing environments. 
In turn, the second subgroup would bring together the works of Cohen and Levinthal (1990) and Zahra and George (2002) dedicated to the capabilities which are available to a firm when it comes to recognising the value of new knowledge arrived from external sources, to assimilating it and to applying it for commercial purposes - that is, to the 'absorption capability' construct. The work of Leonard-Barton (1992), which has as its aim to examine the nature and strategic relevance of a firm's core capabilities, which can eventually become rigidities in rapidly-changing contexts, as well as that of Kogut and Zander (1992), where its authors analyse how knowledge is recombined through both internal and external learning, thus giving rise to what these authors call 'combinative capabilities,' would belong to this second group too.

As for Cluster 5, it includes the papers by Fornell and Larcker (1981), Bagozzi and Youjae (1988), Podsakoff et al. (2003) and Anderson and Gerbing (1988), along with the book by Hair et al. (1998) in its different editions, all of which deal with quantitative methodologies and research techniques.

The works of Atuahene-Gima (2005), Kyriakopoulos and Moorman (2004), Armstrong and Evertong (1977) and Jaworski and Kohli (1993) - all of them published in marketing journals such as Journal of Marketing or Journal of Marketing Research - about the extent to which the impact of ambidexterity on organisational performance could be moderated by the firm's greater or lesser orientation to the market - by way of example, Atuahene-Grima (2005) found that organisations lacking a strong market orientation show a worse performance than those which do have such an orientation - together with the papers by Aiken and West (1991) and Podsakoff and Organ (1986), would shape a second subgroup within this same cluster.

Cluster 6 comprises the works by Raisch et al. (2009), Jansen et al. (2009), Cao et al. (2009), Andriopoulos and Lewis (2009), Mom et al. (2009), Rothaermel and Alexandre (2009), Simsek (2009), Simsek et al. (2009), O'Reilly and Tushman (2008) and Gilbert (2005). The aim sought in all of them is to make progress in the knowledge of organisational ambidexterity, its - structural and/or contextual - background, some of the factors which could positively or negatively moderate the impact of exploratory or exploitative types of learning on firm performance or, even though different empirical studies seem to suggest a positive relationship between ambidexterity and performance, the results obtained by the organisation after developing an ambidextrous behaviour.

The works of Lin et al. (2007), Im and Rai (2008), Lavie and Rosenkopf (2006) and Rothaermel and Deeds (2004) about long-term inter-organisational links and organisational ambidexterity or about how a balance between knowledge exploration and exploitation can be achieved through the creation of strategic alliances shape a second subgroup of papers inside this same cluster.

In turn, Cluster 7 - the same as the already described Cluster 3 - allows us to check the existence of three possible subgroups.

The first subgroup would include the works by Jansen et al. (2006), Auh and Menguc (2005), Katila and Ahuja (2002), Floyd and Lane (2000), Ghemawat and Ricart (1993), Duncan (1976), Adler et al. (1999) and O'Reilly and Tushman (2004); eight documents in total, seven papers and one chapter in a book. Authors such as Duncan (1976) argue that firms need to define dual organisational structures in order to implement their innovation processes and achieve success and survival in the long run. Other works such as those of Auh and Menguc (2005), Adler et al. (1999), Ghemawat and Ricart (1993) or Floyd and Lane (2000) contain a discussion about the ability of organisations which might clearly be considered ambidextrous by O'Reilly and Tushman (2004) to balance or 
offset certain tensions and, subsequently, to fulfil aims which appear to be contradictory to each other, namely: 'flexibility' vs. 'efficiency,' 'exploration' vs. 'exploitation,' 'static' vs. 'dynamic' efficiency; or, as highlighted by Floyd and Lane (2000), to renovate themselves through the exploitation of their current competences while simultaneously exploring other new ones.

The second subgroup would gather the works of Siggelkow and Levinthal (2003), Burns and Stalker (1961), Lawrence and Lorsch (1967) and Thompson (1967). Particularly the first of these works, the one written by Siggelkow and Levinthal (2003) would on the whole deal, as it were, with the structuring of organisations and its impact on organisational performance - this being an issue which dates back to the classic papers by Burns and Stalker (1961) on mechanistic and organic structures, Lawrence and Lorsch (1967) and Thompson (1967).

As for the third subgroup analysed, it would be formed by the works of Rosenkopf and Nerkar (2001), McGrath (2001), Burgelman (2002), Levitt and March (1988), and Holmqvist (2004), all of them research papers. Based on the assumption that organisations learn not only from their own experience but also from other organisations' experience (Levitt and March, 1988), these works focus, amongst other issues, on the exploration and exploitation of new knowledge, the knowledge processes which serve as the basis for a firm to develop innovations as well as for its ability to innovate - the access to knowledge and experience situated close to the firm's technological base, for instance, would make it possible to introduce incremental improvements directly linked to the specific requirements of a particular product - or the strategies which firms are likely to develop for the purpose of undertaking knowledge exploration (Holmqvist, 2004; McGrath, 2001; Rosenkopf and Nerkar, 2001). As an example, Rosenkopf and Nerkar (2001) distinguish in their paper four types of exploratory strategies depending both on the extent to which the firm crosses the organisational boundaries and on the degree to which technological limits are expanded: local exploration; radical; through the expansion of internal limits; and through the expansion of external limits. As for the aforementioned knowledge processes, Holmqvist (2004) described them from two basic dimensions: the (intra- or inter-organisational) provenance of knowledge; and the type of knowledge implemented.

Finally, Cluster 8 includes the works of Raisch and Birkinshaw (2008), Lubatkin et al. (2006), Smith and Tushman (2005), March (1991), Gibson and Birkinshaw (2004), He and Wong (2004), Tushman and O'Reilly (1996), Benner and Tushman (2003), Gupta et al. (2006) and Levinthal and March (1993); a total of ten documents which are all research papers - nine of them being among the ten research works most often cited in the 283 papers examined here. Among these works are, to quote but a few, the seminal paper by March (1991) and the work of Tushman and O'Reilly (1996), where its authors insist on the idea that organisations need to be ambidextrous in order to ensure their longterm survival, or that of Levinthal and March (1993) about the myopia of learning. With regard to the remaining works, papers like those written by Gibson and Birkinshaw (2004), He and Wong (2004), Lubatkin et al. (2006) or Benner and Tushman (2003), for instance, offer empirical evidence on the positive impact exerted by ambidexterity on the organisation's performance or on how the activities oriented to knowledge exploitation have a positive influence on the results achieved by the firm before stable or easily predictable environments, whereas the ability to develop new technological and marketrelated capabilities would become essential in ever-changing environments. 
There are clear main implications of the analysis developed on the emergence of a generally accepted theory on the capability analysed.

As indicated in the conclusions of this paper, they include the need to integrate the different analysis frameworks, from knowledge management or the Knowledge-based Theory of the Firm to the perspective of dynamic capabilities and including other theoretical approaches for an adequate understanding of the phenomenon analysed. In the opinion of the authors of this paper, the capability of an organisation to be ambidextrous is best explained through the holistic integration of the principal theoretical approaches.

On another side, the combination of an internal perspective on the different ways of achieving ambidexterity with an external approach in which the ecosystem of the firm rather than the firm itself is considered as the main unit of analysis is also necessary. There is also a possible gap that emerges in the study: the need to analyse the microfoundations of this organisational capability.

It is also important to study the main antecedents and the conditions necessary to achieve ambidexterity and its impact on performance.

To conclude, a visualisation or graphic representation of the 'intellectual structure' or 'knowledge base' of the research analysed as a result of using VOSviewer ${ }^{\circledR}$ is provided below.

VOSviewer® is a computer application specifically designed to build and visualise large scientific knowledge maps or domains - the construction of maps from bibliographic information is also known as 'scientography,' a term which is hardly used in the literature, though, possibly due to the proliferation of others such as 'domain visualisation' or 'knowledge domains' related to the same idea - paying special attention to their graphic representation. This tool was developed by the Centre for Science and Technology Studies at Leiden University (the Netherlands) and can be used free of charge.

It is also worth highlighting, however, that, although VOSviewer ${ }^{\circledR}$ can be used to build and visualise scientific maps from any kind of co-occurrence data, the application does not permit to create any kind of bibliometric network whatsoever. Neither does this tool have preprocessing capacities, which makes it necessary to use some external software - Bibexcel ${ }^{\circledR}$ and Pajeck ${ }^{\circledR}$ in our case - to prepare the data for their subsequent analysis and representation.

In terms of positioning elements on the map, the analysed application utilises the VOS positioning technique (Van Eck and Waltman, 2010), which builds a similarity matrix on the basis of a co-occurrence matrix - the user must previously create that matrix and load it into the tool - using the so-called 'association strength' as a similarity measure to normalise the network (Coulter et al., 1998; Van Eck et al., 2010), also referred to as 'proximity index' (Peter and Van Raan, 1993; Rip and Courtial, 1984) or 'probabilistic affinity index' (Zitt et al., 2000). The VOS technique (see Figure 1) builds a two-dimensional map where the elements are positioned in such a way that the distances between any pair of elements reflect their degree of similarity in the most accurate possible way. Each element is represented by a tag and a circle on the map. The more important an element is, the larger size its tag will have and the greater volume its associated circle will occupy. 
Figure 1 Intellectual structure or knowledge base of the research developed in relation to the construct 'organisational ambidexterity': visualisation performed using VOSviewerC -map created using VOS mapping and clustering techniques

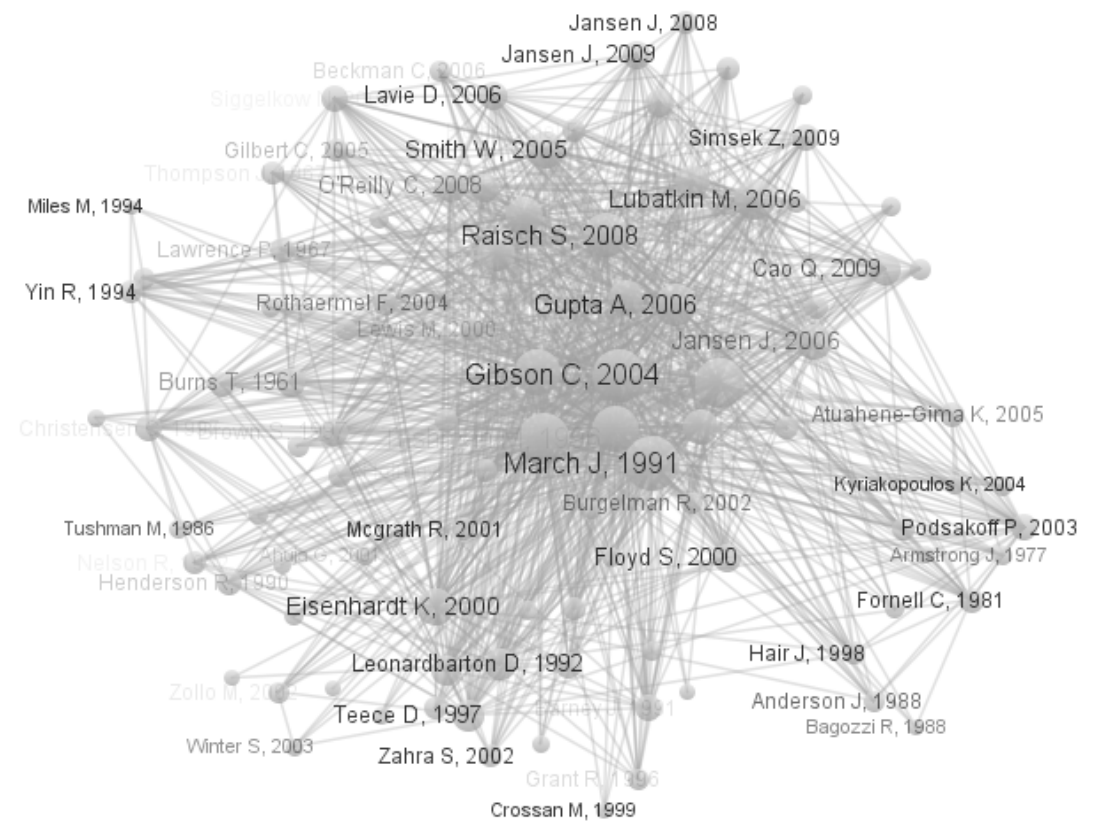

\section{Conclusions and limitations}

Thanks to the use of citation analyses and ACAs together with SNA, the research developed here allows us analyse and represent the intellectual structure or base of research on organisational ambidexterity.

More precisely, and as explained in the abstract of the present paper, a total of 283 research papers which appeared in the journal California Management Review after the publication in the summer of 1996 of the seminal work by Tushman and O'Reilly III entitled 'Ambidextrous organizations: managing evolutionary and revolutionary change', where these authors suggested that organisations need to explore and exploit simultaneously if they want to be ambidextrous, were used for this purpose - i.e., analysing and representing the intellectual structure or base of research on organisational ambidexterity -, which allowed us to draw a number of important conclusions in this regard, such as the markedly multidisciplinary nature shown by the research undertaken in connection with this construct. From such point of view, our findings in this research work do nothing but corroborate those of other previous more qualitative studies and reviews of the literature such as the one carried out by Raisch and Birkinshaw (2008), according to which ambidexterity is ultimately rooted in a variety of research 'streams': from technological innovation to organisation design, going through such theoretical fields or perspectives as: strategic management; inter-organisational networks, strategic alliances or cooperation agreements between forms; or knowledge management inside the firm. 
In the literature dedicated to firm strategic management, to quote but one example, analysis perspectives such as the Resource-Based View of the Firm (RBV), mainly knowledge, or the dynamic capabilities approach, have been used in the study of organisational ambidexterity. For instance, O'Reilly and Tushman $(2008,2013)$ conceive ambidexterity as a dynamic capability which enables the firm to orient itself toward exploration and exploitation depending on the business environment conditions.

On another level, it additionally deserves to be stressed that the research work presented here - along with that of Nosella et al. (2012) - is one of the few scientometric studies performed to date about the scientific production developed around this research object, the analysis method used in our case being the joint citations analysis ${ }^{5}$.

This type of analysis, known as joint citations or co-citation analysis and introduced by Small (1973), starts from the premise that a certain thematic similarity, as well an intellectual connection within the field analysed, exists - at least from the citing author's point of view [McCain, (1990), p.443] - between two or more documents which are co-cited (that is, which are jointly cited in a third work published subsequently); and that the higher the co-citation frequency, the more affinity will exist between them (Cawkell, 1976; Garfield et al., 1978; Marshakova, 1973; Small, 1973), thus allowing to see them as belonging to the same 'research front' (Culnan, 1986; de Solla Price, 1965). The intensity of this relationship will be determined by the number of citing or source documents which contain the same pair of documents amongst their references. If it is assumed that the highly cited documents represent the key concepts, methods or experiments developed in a scientific field, such co-citation patterns could then be used to identify and visualise the relationships between those key ideas (Small, 1973). In 1981, White and Griffith proposed ACA as a new technique that could improve the knowledge about the intellectual structure of scientific disciplines, understanding as 'author' the set of works written by the same person. In this context, co-citation occurs when an author cites the pair of documents of any other two given authors amongst his bibliographic references.

Therefore, based on the previous set of assumptions, it could actually be stated, also by way of conclusion, that the 'author' who undoubtedly seems to have more decisively influenced the development of this study object is J.G. March who, in his reflection on organisations and their dynamics, draws a distinction between exploration and exploitation and claims that an essential requirement for organisations' intelligent adaptation, and for their long-term survival, is to maintain an adequate balance between the exploitation of what is already known and the exploration of what can eventually get to be known, even if this implies important contradictions and tensions which the organisation will be forced to cope with. The works of Gibson and Birkinshaw (2004), Tushman and O'Reilly (1996) or He and Wong (2004) and, consequently, their authors too, stand out - together with that of March (1991) - as being some of the most cited and co-cited by the scientific literature examined.

With regard to its possible limitations, the present study shares with other works of the same nature a number of significant limitations which stem directly from the utilisation of the bibliometric techniques implemented in citation analyses and ACAs. Such limitations are mainly due to the fact that the said analyses are independent from the context in which they are developed. It is generally difficult to predict what proportion of the citation has to do with the intrinsic quality of the work cited and what proportion corresponds to other factors such as the prestige of the journal analysed or of the institution to which the author belongs, the possibility of referring to other works 
previously published by the citing author, spurious reasons, or even the implementation of a deliberate strategy which permits to ensure the publication of a particular paper in a specific journal, which would imply including other papers published in the same journal amongst the references cited. In any case, and regardless of the reasons why authors cite, the theoretical foundation from philosophy and sociology of science remains the same: the joint citation is made by the citing author whose work contributes to the cumulative progress of science, by repeating old links and trying to find new relationships in previous contributions. Another relevant limitation has to do with the fact that a research work needs time to become influential within a specific research area. To this must also be added - in relation to an analysis like ours - that the existence of a certain degree of subjectivity can hardly be denied or rejected when one has to make a decision about the number of authors that will be finally included in the analysis.

\section{References}

Abernathy, W. and Clark, K. (1985) 'Innovation: mapping the winds of creative destruction', Research Policy, Vol. 14, No. 1, pp.3-22.

Adler, P., Goldoftas, B. and Levine, D.I. (1999) 'Flexibility versus efficiency? A case study of model changeovers in the Toyota production system', Organization Science, Vol. 10, No. 1, pp.43-68.

Ahlgren, P., Jarneving, B. and Rousseau, R. (2003) 'Requirements for a cocitation similarity measure, with special reference to Pearson's correlation coefficient', Journal of the American Society for Information Science and Technology, Vol. 54, No. 6, pp.550-560.

Ahlgren, P., Jarneving, B. and Rousseau, R. (2004) 'Author cocitation analysis and Pearson's r', Journal of the American Society for Information Science and Technology, Vol. 55, No. 9, p.843.

Ahuja, G. and Lampert, C.M. (2001) 'Entrepreneurship in the large corporation', Strategic Management Journal, Vol. 22, Nos. 6-7, pp.521-543.

Aiken, L.S. and West, S.G. (1991) Multiple Regression: Testing and Interpreting Interactions, Sage Publications, Thousand Oaks, CA.

Anderson, J.C. and Gerbing, D.W. (1988) 'Structural equation modeling in practice: a review and recommended two-step approach', Psychological Bulletin, Vol. 103, No. 3, pp.411-423.

Andriopoulos, C. and Lewis, M. (2009) 'Exploitation-exploration tensions and organizational ambidexterity: managing paradoxes of innovation', Organization Science, Vol. 20, No. 4, pp.696-717.

Argyris, C. and Schön, D. (1978) Organizational Learning: A Theory of Action Perspective, Addison-Wesley, Reading, MA.

Armstrong, J.S. and Evertong, T.S. (1977) 'Estimating nonresponse bias in mail surveys', Journal of Marketing Research, Vol. 14, No. 3, pp.396-402.

Atuahene-Gima, K. (2005) 'Resolving the capability - rigidity paradox in new product innovation', Journal of Marketing, Vol. 69, No. 4, pp.61-83.

Auh, S. and Menguc, B. (2005) 'Balancing exploration and exploitation: the moderating role of competitive intensity', Journal of Business Research, Vol. 58, No. 12, pp.1652-1661.

Bagozzi, R. and Youjae, Y. (1988) 'On the evaluation of structural equations models', Journal of the Academy of Marketing Science, Vol. 16, No. 1, pp.74-94.

Barney, J. (1991) 'Firm resources and sustained competitive advantage', Journal of Management, Vol. 17, No. 1, pp.99-120. 
Baron, R.M. and Kenny, D.A. (1986) 'The moderator-mediator variable distinction in social psychological research: conceptual, strategic, and statistical considerations', Journal of Personality and Social Psychology, Vol. 51, No. 6, pp.1173-1182.

Beckman, C.M. (2006) 'The influence of founding team company affiliations on firm behavior', Academy of Management Journal, Vol. 49, No. 4, pp.741-758.

Benner, M.J. and Tushman, M.L. (2002) 'Process management and technological innovation. A longitudinal study of the photography and paint industries', Administrative Science Quarterly, Vol. 47, No. 4, pp.676-706.

Benner, M.J. and Tushman, M.L. (2003) 'Exploitation, exploration, and process management: the productivity dilemma revisited', Academy of Management Review, Vol. 28, No. 2, pp.238-256.

Birkinshaw, J. and Gibson, C. (2004) 'Building ambidexterity into an organization', MIT. Sloan Management Review, Vol. 45, No. 4, pp.47-55.

Birkinshaw, J. and Gupta, A.K. (2013) 'Clarifying the distinctive contribution of ambidexterity of the field of organization studies', Academy of Management Perspectives, Vol. 27, No. 4, pp.287-298.

Brown, S.L. and Eisenhardt, K.M. (1997) 'The art of continuous change: linking complexity theory and time-paced evolution in relentlessly shifting organizations', Administrative Science Quarterly, Vol. 42, No. 1, pp.1-34.

Burgelman, R.A. (1991) 'Intraorganizational ecology of strategy making and organizational adaptation: theory and field research', Organization Science, Vol. 2, No. 3, pp.239-262.

Burgelman, R.A. (2002) 'Strategy as vector and the inertia of coevolutionary lock-in', Administrative Science Quarterly, Vol. 47, No. 2, pp.325-357.

Burns, T. and Stalker, M. (1961) The Management of Innovation, Tavistock, London.

Callon, M., Courtial, J.P. and Penan, H. (1993) Cienciometría. La medición de la actividad cientifica: de la bibliometría a la vigilancia tecnológica [Scientometrics. The Measurement of Scientific Activity: From Bibliometrics to Technological Vigilance], Ediciones Trea, S.L., Gijón, Spain.

Cao, Q., Gedajlovic, E.R. and Zhang, H. (2009) 'Unpacking organizational ambidexterity: dimensions, contingencies, and synergistic effects', Organization Science, Vol. 20, No. 4, pp.781-796.

Cawkell, A.E. (1976) 'Understanding science by analysing its literature', Essays of an Information Scientist, Vol. 2, pp.543-549.

Chesbrough, H.W. (2003) Open Innovation: The New Imperative for Creating and Profiting from Technology, Harvard University Press, Cambridge, MA.

Christensen, C.M. (1997) The Innovator's Dilemma: When New Technologies Cause Great Firms to Fail, Harvard Business School Press, Boston, MA.

Cohen, W.M. and Levinthal, D.A. (1990) 'Absorptive capacity: a new perspective on learning and innovation', Administrative Science Quarterly, Vol. 35, No. 1, pp.128-152.

Coulter, N., Monarch, I. and Konda, S. (1998) 'Software engineering as seen through its research literature: a study in co-word analysis', Journal of the American Society for Information Science, Vol. 49, No. 13, pp.1206-1223.

Crossan, M.M., Lane, H.W. and White, R.E. (1999) 'An organizational learning framework: from intuition to institution', Academy of Management Review, Vol. 24, No. 3, pp.522-537.

Culnan, M.J. (1986) 'The intellectual development of management information systems, 1972-1982: A co-citation analysis', Management Science, Vol. 32, No. 2, pp.156-172.

Cyert, R.M. and March, J.G. (1963) A Behavioral Theory of the Firm, Prentice Hall, Englewood Cliffs, NJ.

Damanpour, F. (1991) 'Organizational innovation: a meta-analysis of effects of determinants and moderators', Academy of Management Journal, Vol. 34, No. 3, pp.555-590. 
Danneels, E. (2002) 'The dynamics of product innovation and firm competences', Strategic Management Journal, Vol. 23, No. 12, pp.1095-1121.

de Solla Price, D.J. (1965) 'Networks of scientific papers', Science, Vol. 149, No. 3683, pp.510-515.

Duncan, R. (1976) 'The ambidextrous organization: designing dual structures for innovation', in Kilmann, R., Pondy, L. and Slevin, D. (Eds.): The Management of Organization Design, Vol. I, pp.167-188, North Holland, New York, NY.

Eisenhardt, K.M. (1989) 'Building theories from case study research', Academy of Management Review, Vol. 14, No. 4, pp.532-550.

Eisenhardt, K.M. and Martin, J.A. (2000) 'Dynamics capabilities: what are they?', Strategic Management Journal, Vol. 21, Nos. 10-11, pp.1105-1121.

Floyd, S.W. and Lane, P.J. (2000) 'Strategizing throughout the organization: managing role conflict in strategic renewal', Academy of Management Review, Vol. 25, No. 1, pp.154-177.

Fornell, C. and Larcker, D.F. (1981) 'Evaluating structural equation models with unobservable variables and measurement error', Journal of Marketing Research, Vol. 18, No. 1, pp.39-50.

Garfield, E., Malin, M.V. and Small, H. (1978) 'Citation data as science indicators', in Elkana, Y., Lederberg, J., Merton, R.K., Thackray, A. and Zuckerman, H. (Eds.): Toward a Metric of Science: The Advent of Science Indicators, pp.179-208, John Wiley \& Sons, New York, NY.

Ghemawat, P. and Ricart, J.E. (1993) 'The organizational tension between static and dynamic efficiency', Strategic Management Journal, Vol. 14, No. S2, pp.59-74.

Ghoshal, S. and Bartlett, C.A. (1994) 'Linking organizational context and managerial action: the dimensions of quality of management', Strategic Management Journal, Vol. 15, No. S2, pp.91-112.

Gibson, C.B. and Birkinshaw, J. (2004) 'The antecedents, consequences, and mediating role of organizational ambidexterity', Academy of Management Journal, Vol. 47, No. 2, pp.209-226.

Gilbert, C. (2005) 'Unbundling the structure of inertia: resource versus routine rigidity', Academy of Management Journal, Vol. 48, No. 5, pp.741-763.

Gmür, M. (2003) 'Co-citation analysis and the search for invisible colleges: a methodological evaluation', Scientometrics, Vol. 57, No. 1, pp.27-57.

Grant, R.M. (1996) 'Toward a knowledge-based theory of the firm', Strategic Management Journal, Vol. 17, No. S2, pp.109-122.

Greene, D., Freyne, J., Smyth, B. and Cunningham, P. (2008) 'An analysis of research themes in the CBR Conference Literature', in Althoff, K., Bergmann, R., Miner, M. and Hanft, A. (Eds.): Advances in Case-Based Reasoning: 9th European Conference, ECCBR 2008 Proceedings, 1-4 September, pp.18-43, Springer, Berlin, Trier, Germany.

Griffiths, A., Robinson, L.A. and Willet, P. (1984) 'Hierarchic agglomerative clustering methods for automatic document classification', Journal of Documentation, Vol. 40, No. 3, pp.175-205.

Gupta, A.K., Smith, K.G. and Shalley, C.E. (2006) 'The interplay between exploration and exploitation', Academy of Management Journal, Vol. 49, No. 4, pp.693-706.

Hair Jr., J.F., Anderson, R.E., Tatham, R.L. and Black, W.C. (1998) Multivariate Data Analysis, 5th ed., Prentice Hall, Englewood Cliffs, NJ.

Hannan, M. and Freeman, J. (1984) 'Structural inertia and organizational change', American Sociological Review, Vol. 49, No. 2, pp.149-164.

He, Z.L. and Wong, P.K. (2004) 'Exploration vs. exploitation: an empirical test of the ambidexterity hypothesis', Organization Science, Vol. 15, No. 4, pp.481-494.

Henderson, R.M. and Clark, K.B. (1990) 'Architectural innovation: the reconfiguration of existing product technologies and the failure of established firms', Administrative Science Quarterly, Vol. 35, No. 1, pp.9-30. 
Holmqvist, M. (2004) 'Experiential learning processes of exploitation and exploration within and between organizations: an empirical study of product development', Organization Science, Vol. 15, No. 1, pp.70-81.

Im, G. and Rai, A. (2008) 'Knowledge sharing ambidexterity in long-term interorganizational relationships', Management Science, Vol. 54, No. 7, pp.1281-1296.

Jansen, J.J.P., George, G., Van den Bosch, F.A.J. and Volberda, H.W. (2008) 'Senior team attributes and organizational ambidexterity: the moderating role of transformational leadership', Journal of Management Studies, Vol. 45, No. 5, pp.982-1007.

Jansen, J.J.P., Tempelaar, M.P., Van den Boch, F.A.J. and Volberda, H.W. (2009) 'Structural differentiation and ambidexterity: the mediating role of integration mechanisms', Organization Science, Vol. 20, No. 4, pp.797-811.

Jansen, J.J.P., Van den Bosch, F.A.J. and Volberda, H.W. (2005) 'Managing potential and realized absorptive capacity: how do organizational antecedents matter?', Academy of Management Journal, Vol. 48, No. 6, pp.999-1015.

Jansen, J.J.P., Van den Bosch, F.A.J. and Volberda, H.W. (2006) 'Exploratory innovation, exploitative innovation, and performance: effects of organizational antecedents and environmental moderators', Management Science, Vol. 52, No. 11, pp.1661-1674.

Jaworski, B. and Kohli, A. (1993) 'Market orientation: antecedents and consequences', Journal of Marketing, July, Vol. 57, No. 3, pp.53-70.

Katila, R. and Ahuja, G. (2002) 'Something old, something new: a longitudinal study of search behavior and new product introduction', Academy of Management Journal, Vol. 45, No. 6, pp.1183-1194.

Kauppila, O.P. (2010) 'Creating ambidexterity by integrating and balancing structurally separate interorganizational partnerships', Strategic Organization, Vol. 8, No. 4, pp.283-312.

Kogut, B. and Zander, U. (1992) 'Knowledge of the firm, combinative capabilities, and the replication of technology', Organization Science, Vol. 3, No. 3, pp.383-397.

Kristal, M.M., Huang, X. and Roth, A.V. (2010) 'The effect of an ambidextrous supply chain strategy on combinative capabilities and business performance', Journal of Operations Management, Vol. 69, No. 7, pp.415-429.

Kyriakopoulos, K. and Moorman, C. (2004) 'Tradeoffs in marketing exploitation and exploration strategies: the overlooker role of marketing orientation', International Journal of Research in Marketing, Vol. 21, No. 3, pp.219-240.

Lavie, D. and Rosenkopf, L. (2006) 'Balancing exploration and exploitation in alliance formation', Academy of Management Journal, Vol. 49, No. 4, pp.797-818.

Lavie, D., Kang, J. and Rosenkopf, L. (2011) 'Balance within and across domains: the performance implications of exploration and exploitation in alliances', Organization Science, Vol. 22, No. 6, pp. 1517-1538.

Lavie, D., Stettner, U. and Tushman, M.L. (2010) 'Exploration and exploitation within and across organizations', Academy of Management Annals, Vol. 4, No. 1, pp.109-155.

Lawrence, P.R. and Lorsch, J.W. (1967) Organization and Environment: Managing Differentiation and Integration, Harvard University, Boston, MA.

Leonard-Barton, D. (1992) 'Core capabilities and core rigidities: a paradox in managing new product development', Strategic Management Journal, Vol. 13, No. S1, pp.111-125.

Levinthal, D.A. and March, J.G. (1993) 'The myopia of learning', Strategic Management Journal, Vol. 14, No. S2, pp.95-112.

Levitt, B. and March, J.G. (1988) 'Organizational learning', Annual Review of Sociology, Vol. 14, pp.319-340.

Lewis, M. (2000) 'Exploring paradox: toward a more comprehensive guide', Academy of Management Review, Vol. 25, No. 4, pp.760-776. 
Lin, Z., Yang, H. and Demirkan, I. (1997) 'The performance consequences of ambidexterity in strategic alliance formations: empirical investigation and computational theorizing', Organization Science, Vol. 53, No. 10, pp.1645-1658.

Lubatkin, M.H., Simsek, Z., Ling, Y. and Veiga, J.F. (2006) 'Ambidexterity and performance in small-to-medium-sized firms: the pivotal role of top management team behavioral integration', Journal of Management, Vol. 32, No. 5, pp.646-672.

March, J.G. (1991) 'Exploration and exploitation in organizational learning', Organization Science, Vol. 2, No. 1, pp.71-87.

March, J.G. and Simon, H.A. (1958) Organizations, John Wiley \& Sons, New York, NY.

Marshakova, I.V. (1973) 'System of document connection based on references', Nauchno-Teknichescaya Informatisya, Seriya 2, pp.3-8.

McCain, K.W. (1990) 'Mapping authors in intellectual space: a technical overview', Journal of the American Society for Information Science, Vol. 41, No. 6, pp.433-443.

McGrath, R.G. (2001) 'Exploratory learning, innovative capacity, and managerial oversight', Academy of Management Journal, Vol. 44, No. 1, pp.118-131.

Miles, M.B. and Huberman, A.M. (1994) Qualitative Data Analysis: An Expanded Sourcebook, Sage Publications, London.

Mom, T.J.M., Van den Bosch, F.A.J. and Volberda, H.W. (2007) 'Investigating manager's exploration and exploitation activities: the influence of top-down, bottom-up, and horizontal knowledge inflows', Journal of Management Studies, Vol. 44, No. 6, pp.910-931.

Mom, T.J.M., Van den Bosch, F.A.J. and Volberda, H.W. (2009) 'Understanding variation in managers' ambidexterity: investigating direct and interaction effects of formal structural and personal coordination mechanisms', Organization Science, Vol. 20, No. 4, pp.812-828.

Nahapiet, J. and Ghoshal, S. (1998) 'Social capital, intellectual capital, and the organizational advantage', Academy of Management Review, Vol. 23, No. 2, pp.242-266.

Nelson, R.R. and Winter, S.G. (1982) An Evolutionary Theory of Economic Change, Belknap, Boston, MA.

Nonaka, I. and Takeuchi, H. (1995) The Knowledge-Creating Company: How Japanese Companies Create the Dynamics of Innovation, Oxford University Press, New York, NY.

Nosella, A., Cantarello, S. and Filippini, R. (2012) 'The intellectual structure of organizational ambidexterity: a bibliographic investigation into the state of the art', Strategic Organization, Vol. 10, No. 4, pp.450-465.

O'Reilly, C.A. and Tushman, M.L. (2004) 'The ambidextrous organization', Harvard Business Review, Vol. 82, No. 4, pp.74-81.

O'Reilly, C.A. and Tushman, M.L. (2008) 'Ambidexterity as a dynamic capability: resolving the innovator's dilemma', Research in Organizational Behavior, Vol. 28, No. 1, pp.185-206.

O'Reilly, C.A. and Tushman, M.L. (2013) 'Organizational ambidexterity: past, present and future', Academy of Management Perspectives, Vol. 27, No. 4, pp.324-338.

Peters, H.P.F. and Van Raan, A.F.J. (1993) 'Co-word-based science maps of chemical engineering. Part I: representations by direct multidimensional scaling', Research Policy, Vol. 22, No. 1, pp. $23-45$.

Podsakoff, P.M. and Organ, D.W. (1986) 'Self-reports in organizational research: problems and prospects', Journal of Management, Vol. 12, No. 4, pp.531-544.

Podsakoff, P.M., MacKenzie, S.B., Lee, J.Y. and Podsakoff, N.P. (2003) 'Common method biases in behavioral research: a critical review of the literature and recommended remedies', Journal of Applied Psychology, Vol. 88, No. 5, pp.879-903.

Porter, M.E. (1980) Competitive Strategy: Techniques for Analyzing Industries and Competitors, The Free Press, New York, NY.

Powell, W.W., Koput, K.W. and Smith-Doerr, L. (1996) 'Interorganizational collaboration and the locus of innovation: networks of learning in biotechnology', Administrative Science Quarterly, Vol. 41, No. 1, pp.116-145. 
Raisch, S. and Birkinshaw, J. (2008) 'Organizational ambidexterity: antecedents, outcomes, and moderators', Journal of Management, Vol. 34, No. 3, pp.375-409.

Raisch, S., Birkinshaw, J., Probst, G. and Tushman, M.L. (2009) 'Organizational ambidexterity: balancing exploitation and exploration for sustained performance', Organization Science, Vol. 20, No. 4, pp.685-695.

Rip, A. and Courtial, J. (1984) 'Co-word maps of biotechnology: an example of cognitive scientometrics', Scientometrics, Vol. 6, No. 6, pp.381-400.

Rosenkopf, L. and Nerkar, A. (2001) 'Beyond local search: boundary-spanning, exploration, and impact in the optical disk industry', Strategic Management Journal, Vol. 22, No. 4, pp.287-306.

Rothaermel, F.T. and Alexandre, M.T. (2009) 'Ambidexterity in technology sourcing: the moderating role of absorptive capacity', Organization Science, Vol. 20, No. 4, pp.759-780.

Rothaermel, F.T. and Deeds, D.L. (2004) 'Exploration and exploitation alliances in biotechnology: a system of new product development', Strategic Management Journal, Vol. 25, No. 3, pp.201-225.

Russo, A. and Vurro, C. (2010) 'Cross-boundary ambidexterity: balancing exploration and exploitation in the Fuel Cell Industry', European Management Review, Vol. 7, No. 1, pp.30-45.

Schäffer, U., Nevries, P., Fikus, C. and Meyer, M. (2011) 'Is finance research a 'normal science'? A bibliometric study of the structure and development of finance research from 1988 to 2007', Schmalenbach Business Review, Vol. 63, No. 4, pp.189-225.

Schildt, H.A., Zahra, S.A. and Sillanpää, A. (2006) 'Scholarly communities in entrepreneurship research: a co-citation analysis', Entrepreneurship Theory and Practice, Vol. 30, No. 3, pp.399-415.

Sheremata, W.A. (2000) 'Centrifugal and centripetal forces in radical new product development under time pressure', Academy of Management Review, Vol. 25, No. 2, pp.389-408.

Siggelkow, N. and Levinthal, D.A. (2003) 'Temporarily divide to conquer: centralized, decentralized, and reintegrated organizational approaches to exploration and adaptation', Organization Science, Vol. 14, No. 6, pp.650-669.

Simsek, Z. (2009) 'Organizational ambidexterity: towards a multilevel understanding', Journal of Management Studies, Vol. 46, No. 9, pp.597-624.

Simsek, Z., Heavey, C., Veiga, J.F. and Souder, D. (2009) 'A typology for aligning organizational ambidexterity's conceptualizations, antecedents, and outcomes', Journal of Management Studies, Vol. 46, No. 5, pp.864-894.

Small, H. (1973) 'Co-citation in the scientific literature: a new measure of the relation between two documents', Journal of the American Society for Information Science, Vol. 24, No. 4, pp.265-269.

Smith, W.K. and Tushman, M.L. (2005) 'Managing strategic contradictions: a top management model for managing innovation streams', Organization Science, Vol. 16, No. 5, pp.522-536.

Stettner, U. and Lavie, D. (2014) 'Ambidexterity under scrutiny: exploration and exploitation via internal organization, alliances and acquisitions', Strategic Management Journal, Vol. 35, No. 13, pp.1903-1929.

Teece, D.J. (2007) 'Explicating dynamic capabilities: the nature and microfoundations of (sustainable) enterprise performance', Strategic Management Journal, Vol. 28, No. 13, pp.1319-1350.

Teece, D.J., Pisano, G. and Shuen, A. (1997) 'Dynamic capabilities and strategic management', Strategic Management Journal, Vol. 18, No. 7, pp.509-533.

Thompson, J.D. (1967) Organizations in Action: Social Science Bases of Administrative Theory, McGraw-Hill, New York, NY.

Tripsas, M. and Gavetti, G. (2000) 'Capabilities, cognition, and inertia: evidence from digital imaging', Strategic Management Journal, Vol. 21, Nos. 10-11, pp.1147-1161. 
Tushman, M.L. and Anderson, P. (1986) 'Technological discontinuities and organizational environments', Administrative Science Quarterly, Vol. 31, No. 3, pp.439-465.

Tushman, M.L. and O’Reilly, C.A. (1996) 'Ambidextrous organizations: managing evolutionary and revolutionary change', California Management Review, Vol. 38, No. 4, pp.8-30.

Tushman, M.L. and O'Reilly, C.A. (1997) Winning through Innovation: A Practical Guide to Leading Organizational Change and Renewal, Harvard Business School Press, Boston, MA.

Van Eck, N.J. and Waltman, L. (2008) 'Appropriate similarity measures for author co-citation analysis', Journal of the American Society for Information Science and Technology, Vol. 59, No. 10, pp.1653-1661.

Van Eck, N.J. and Waltman, L. (2009) 'How to normalize co-occurrence data? An analysis of some well-known similarity measures', Journal of the American Society for Information Science and Technology, Vol. 60, No. 8, pp.1635-1651.

Van Eck, N.J. and Waltman, L. (2010) 'Software survey: VOS viewer, a computer program for bibliometric mapping', Scientometrics, Vol. 84, No. 2, pp.523-538.

Van Eck, N.J., Waltman, L., Dekker, R. and Van den Berg, J. (2010) 'A comparison of two techniques for bibliometric mapping: multidimensional scaling and VOS', Journal of the American Society for Information Science and Technology, Vol. 61, No. 12, pp.2405-2416.

Vogel, R. and Güttel, W.H. (2013) 'The dynamic capability view in strategic management: a bibliometric review', International Journal of Management Reviews, Vol. 15, No. 4, pp.426-446.

White, H.D. and Griffith, B.C. (1981) 'Author cocitation: a literature measure of intellectual structure', Journal of the American Society for Information Science, Vol. 32, No. 3, pp.163-171.

Winter, S.G. (2003) 'Understanding dynamic capabilities', Strategic Management Journal, Vol. 24, No. 10, pp.991-995.

Yin, R.K. (1984) Case Study Research: Design and Methods, Sage, Beverly Hills, CA.

Zahra, S. and George, G. (2002) 'Absorptive capacity: a review, reconceptualization, and extension', Academy of Management Review, Vol. 27, No. 2, pp.185-203.

Zitt, M. and Bassecoulard, E. (1996) 'Reassessment of co-citation methods for science indicators: effect of methods improving recall rates', Scientometrics, Vol. 37, No. 2, pp.223-244.

Zitt, M., Bassecoulard, E. and Okubo, Y. (2000) 'Shadows of the past in international cooperation: collaboration profiles of the top five producers of science', Scientometrics, Vol. 47, No. 3, pp.627-657.

Zollo, M. and Winter, S.G. (2002) 'Deliberate learning and the evolution of dynamics capabilities', Organization Science, Vol. 13, No. 3, pp.339-351.

\section{Notes}

1 The criteria used to obtain the number of articles to be analysed were as follows: we used the key words of 'organizational ambidexterity' OR 'ambidextrous organizations' in searches of TOPIC in the research areas of 'management' and 'business' in articles published between 1996, the year of publication of the study of Tushman and O'Reilly III: 'Ambidextrous Organizations: Managing Evolutionary and Revolutionary Change', and 2013.

2 On the whole, what the literature actually suggests is that no methodological guide or way of acting has been estab-lished in this respect, which is why the choice usually results from a series of tests so that the possibility exists to obtain a co-citation matrix with a suitable size for its statistical treatment or its graphic representation. This same view is shared by authors such as Schildt et al. (2006, p.401) in connection with the field of Entrepreneurship. 
3 More precisely, such values can be treated in two ways. The first one (White and Griffith, 1981) consists in taking the sum of the three highest values or absolute frequencies on the corresponding row or column -note that it is a symmetrical matrix- and dividing that sum by two, which provides a value that, according to the aforesaid authors, could illustrate the importance of a given paper in the field under study; the other option (McCain, 1990) simply starts from regarding such values as missing data or values and applying the pairwise deletion criterion when carrying out the calculations to be developed; that is, from ignoring the main diagonal values when calculating the correlation coefficients between each pair of documents, for example.

4 Authors such as Tripsas and Gavetti (2000) stress in their paper how difficult it is for the top managers of these companies to adapt their mental schemes or models - essentially based on their own previous experience and on their system of beliefs and cases associated with the reality and the world that surround them - to the new environmental conditions, thus favouring inertia and giving as a result a poor organisational performance insofar as no new capabilities are being developed.

5 The main difference between our paper and that of Nosella et al. (2012) is that the aforementioned authors use the technique of bibliographic coupling in their analysis and we use author co-citation analysis (ACA). The main difference between the two analysis techniques can be found in the work of Vogel and Güttel (2013). 